\title{
Nepal: Food Security, a Localized Institutional Irrigation Perspective on Public Irrigation Systems
}

Upendra Gautam

\begin{abstract}
Oriental philosophers have given top priority to food for orderly state affairs as well as personal wellbeing. In past, Nepal had a strong agricultural economy based on indigenous Farmer Managed Irrigation System (FMIS). State policy helped promote these systems. But contemporary Nepal opted for state control on irrigation water by building large scale public irrigation systems. In the last 43 years of planned development (1957-2002), the government has spent $70 \%$ of US $\$ 1.3$ billion on these systems, covering 30\% of the irrigated area in the country; the remaining $70 \%$ is with the FMIS. Despite the investment, these systems neither promoted themselves as an enterprise nor helped enhance agricultural productivity leading to social insecurity. This social insecurity is reflected in the country's increasing import of food, mass workforce exodus for employment abroad, and added socio-economic vulnerability due to climate change.

Donor and government recommendations centered on (i) expansion of irrigated area, (ii) irrigation management transfer, and (iii) agriculture extension seem to have failed in Nepal. These failures asked for alternative institutional development solutions, whereas public irrigation systems are (i) localized to establish system's operational autonomy with ownership and governance, (ii) treated as a rich resource-base with water, land and labor, and (iii) recognized as cooperative enterprise of local stakeholders by law with authorities to enter into joint actions with relevant partners for promoting commercialization and environmental quality of irrigated agriculture.
\end{abstract}

Key words: Climate change, cooperative venture, Farmer Managed Irrigation System (FMIS), food security, public irrigation system, Nepal

The Chinese social philosopher Confucius (551-479 BC) once listed a number of constituents (essentials) for running state affairs in an orderly manner. They included: constitution, government, military, food, etc. When his disciples continued to ask Confucius to choose the one that was most important, he opted for food. In contemporary Nepal, a large number of people are hungry, poor, and unemployed. In the ancient time, Nepal had its glory and richness of a powerful agricultural economy (Gautam and Khaniya 2010).

\section{Indigenous Systems of Irrigation}

Trigation water has long served as both the spiritual and material foundations of Nepal's community civilization. The rich cultural traditions, arts, artifacts, and architecture of Kathmandu valley are attributed to a network of irrigation systems supporting advanced and intensive agriculture activities. A combination of spiritual mission, royalty, and religious trust (known as guthi) coupled with community initiative for irrigated agriculture has been the driving force in promoting local cooperative enterprises. The state encouraged the development of such trusts. These trusts allocated a portion of their income out of religious performance to assist irrigated agricultural activities on which the livelihoods of the trust's members were dependent.

It is rather fascinating to note that even in the ancient city planning, like that in the layout of Handigaun, the ancient capital of Nepal, irrigated agriculture, as identified with the rural areas, was incorporated in the city landscape in the manner that the available land use was maximized by appropriate zoning for agricultural use, human settlement, market space, water conservation ponds, pasture lands and religious sites (Tiwari 2002).

Before 464 AD, King Shankar Dev constructed Shankhu Rajkulo (Shankhu Royal Canal) tapping water from Sali Nadi (river) for the purpose of drinking and irrigation in the Sankhu town (Pun 2001). During the Lichchavi Period (78-880 AD), the local people developed the indigenous system of integrated water utilization by combining stone water conduits along with the ponds and canals. In the first half of the fifth century, a grave water crisis occurred due to landslide in the capital city in Kathmandu valley, popularly known as Nepal Khaldo (Nepal Valley). To resolve this crisis, the Lichchvi king commissioned a large water supply project, taking advantage of the accidentally created ponds as well as of the existing natural channels of water. This system was later called the Rajkulo (royal canal) (Tiwari 2002).

Argeli Jethi kulo built around $1543-47$ AD in Palpa district in western Nepal represents the example of religious Guthi-(religious trust) supported irrigation system (Pradhan 1989). This system was developed during the rule of King Mani Mukunda Sen I of Palpa. It was built to cultivate rice to generate revenue for meeting the worship expenses of the deity Rishikeshav Narayan, located on the bank of river Kali Gandaki river at Ridhi, in the western district of Palpa.

During the reign of King Baliraj of the Kalyan Dynasty (1400 AD), farmers were supported to build canals in a the more remote far west district of Jumla at an elevation of about 2,500 meters above the sea level (Devkota 2002). Besides state support for irrigation canal construction, local communities have also taken initiative in constructing irrigation channels for paddy cultivation. Along the banks of Tila and Sinja rivers, for example, many community initiated irrigation systems maintained and managed by the community are functioning.

State policies and practices were historically conducive to strengthen community roles in water resource management. They provided top priority to water and 
food security of the people under the active initiative of the local community. In the 17th century, an edict by King Ram Shah of Gorkha mandated that water resourcerelated conflicts were to be settled at the community level. Though such mediation had to take into account local power structures, it allowed community initiatives and governance structures to evolve. Hence, the indigenous tradition of Farmer Managed Irrigation Systems (FMIS) became deeply rooted in Nepalese society over a long period of time. In the directive of King Jitamitra Malla (c. $1682 \mathrm{AD}$ ), a Rajkulo was constructed from Mahadev Danda (some $6 \mathrm{~km}$ from Bhaktapur city), collecting water from Mahadev Khola (stream) at Nagarkot to Sundhara of Thunthu Palace at Durbar Square in the heart of Bhaktapur. In addition to the religious purpose of this water, it was used for irrigation, water mill operation, and drinking water for the city populace, as well as for fish farming. The king also instituted guthi (trust) and formulated rules for the maintenance of these systems (Khaniya 2005; Wright 2000). The Italian religious teachers who visited Nepal in 1704 AD compared Kathmandu with Venice for its water management and settlement pattern.

In $1829 \mathrm{AD}$, during the reign of General Bhimsen Thapa, the first Prime Minister of modern Nepal, a canal was dug out from the pokhari (lake) of Raniban of Kirtipur, 20 kilometers from the heart of Kathmandu. Farmer representatives or persons designated for the purpose could collect water tax for the use of the water at a rate fixed by the government. A system of water tax collection as service charge was in practice in those days, too. The lake was allowed to have other functions as well. Fishery was promoted in these three lakes to generate income for the state (Nepali 1965).

The Rana regime (1846-1951) did not invest except in a few public irrigation systems like Manusmara, Chandra Nahar, Jagadishpur Resevoir (Banganga) in Nepal's central, eastern, and western lowland Terai region. The Ranas allowed the communities to take initiative for irrigation channel construction. Once the irrigation facility was completed, the status of the land was changed and the government was able to collect more revenue without much investment. It was a customary rule that landrevenue from unirrigated land went to local Raja-Rajautas (nobles) and the revenue from the irrigated land went to the central government. As such, the hilly districts did not readily welcome the central administration's role in local irrigation development.

\section{Present State of Irrigation Systems}

It seems that Nepal has not learned from its own history and key institutional character of the indigenous Farmer Managed Irrigation Systems (FMIS); that is, from the long-standing local systems of operational autonomy. Instead, after 1951, the role of the state was expanded and attempts were made to extend the state control on irrigation water through constructing large scale governmentadministered public irrigation systems. By 2002 the area covered by government-administered irrigation systems was 320,000 ha (30\%), while FMIS covered the remaining 70\% (880,000 ha) (Paudel 2059 [2003 AD]; MOAC 2010). The government department provides assistance to FMIS, which contributes about $40 \%$ of the food requirement of the country (Pradhan 2011).
In the planned period of the last 43 years (1957-2002), the government along with multiple donors has invested US $\$ 1.364$ billion in the irrigation sector. This amount was half of the allocation (of US $\$ 2.7$ billion) made altogether to agriculture, irrigation and forestry. According to an expert estimate, out of this amount $30 \%$ has gone to FMIS while $70 \%$ to the government-administered irrigation systems (Paudel 2011).

An analysis of the decade of 1992 to 2002 indicates that the government was preoccupied with maintaining a sort of status quo in terms of average productivity of major crops (paddy, wheat and maize) from the irrigated area. The reality is that less than half of the irrigated area gets irrigation, only in the monsoon season, while less than a fourth of this is fortunate to have year-round irrigation.

Despite the practical feasibility of almost doubling the per hectare productivity (4 MT) of the major crops like paddy, wheat and maize, average crop productivity was clearly on the subsistence side.

\section{Consequences Poor Irrigation Systems}

The net result of the subsistence irrigated agriculture throughout these years has been heightened social insecurity, which is reflected in (a) increasing import of food, (b) mass exodus for employment abroad, and (c) increased socio-economic vulnerability due to climate change.

\section{Food Import}

Nepal has been transformed from a food exporting to food importing country. Over the past few decades, Nepal has not produced enough food to satisfy domestic demand. It has to import food equal to the domestic production deficit (Vaidya 1999). According to the World Food Program (WFP), there was a food deficit of 316,000 metric tons deficit in 2010, an increase by 139 percent over 2009. In 2009, the nation's agricultural trade deficit was US\$ 270 million, up from US\$ 157 million in 2003. Even if prices increase, Nepal will continue to have to import at least the same amount of food, but at substantially more cost. The WFP also reports that about 3.7 million people face risk of food insecurity in Nepal (Sapkota 2011).

The domestic food situation is aggravated by prices that have reached the second highest level since 1990. Rising food prices have triggered a wave of protests across the globe and have forced countries such as India, Russia and Vietnam, among others, to impose embargoes on food grain exports. These events directly or indirectly affect food prices and food availability in Nepal.

A Nepali citizen spends on average $59 \%$ of his/her income on food. Of this, about $58 \%$ are spent on breads/ cereals and $15 \%$ on fruits and vegetables. Since food prices are already high in the domestic market, any further price rise will force more people to scale back discretionary expenditures and savings, which will directly affect investment, economic growth and trade balance (Sapkota 2011).

\section{Mass Exodus}

The daily queues for passports at the Nepal Foreign Ministry and the huge lines of youth at the manpower recruitment facilitation centers indicate that despite 
reports of exploitation, cheating by middlemen, low pay and hardships, the Nepalese are more desperate than ever to go where they can earn more salary.

According to a 2011 ILO report, almost $40 \%$ of Nepal's population will come of working age in the next 15 years. It is ironic that this nation survives on the remittance money sent back by the same people whom it has failed to support. The strategy of successive governments has been to manage Nepal's growing unemployment with a mass exodus, not just of the working population but also of the highly qualified people who could keep a check on the political authority (Acharya 2011).

According to recent data, around 20\% of Nepal's population coming mainly from farming background work abroad. The failure of the government to sustainably improve agriculture and employment has forced them off the land. The fallow fields in the countryside are a testimony to the absence of able-bodied youth (Acharya 2011).

No one has ever counted the illegal numbers who go overland to India, and from there to another country. Nor has anyone taken count of the Indians who are conveniently and profitably employed here. According to a JP Morgan Study, India was the world's largest remittance recipient in 2006-07. The top 10 destination countries for the Indians included the UAE, Saudi Arabia, USA, Bangladesh, Nepal, UK, Sri Lanka, Canada, Kuwait and Oman (Dhawan 2008).

\section{Climate Change}

Melting Himalayan glaciers and other climate change impacts directly pose a new challenge to the water and food security of more than 1.6 billion people in South AsiaNepal included.

Analyzing current trends and scenarios based on projected temperature increases, an Asian Development Bank (ADB) study produced by the International Food Policy Research Institute entitled 'Addressing Climate Change in the Asia and Pacific Region: Building Climate Resilience in the Agriculture Sector' warns that four countries in South Asia-Afghanistan, Bangladesh, India and Nepal- are particularly vulnerable to falling crop yields caused by glacier retreat, floods, droughts, erratic rainfall and other climate change impacts (Stedman 2009).

The study warns that if current trends persist until 2050 (by this time Nepal's population is projected to be 80 million), the yields of irrigated crops in South Asia will decrease significantly- maize $(-17 \%)$, wheat $(-12 \%)$ and rice $(-10 \%)$ - because of climate change-induced heat and water stress. The resulting food scarcity will lead to higher prices and reduced caloric intake across the region.

It should be further noted that almost half of the world's absolute poor live in South Asia, where they tend to depend more on rain-fed agriculture and live in settlements that are highly exposed to climate variability. Thus Nepal will have to face the formidable challenge induced by climate change for which it cannot be held accountable at all.

\section{Addressing the Issues}

For the last 25 years, the government and donor recommendations to improve the food security situation in Nepal has centered on (i) expansion of irrigated area, (ii) irrigation management transfer (Abernethy 2000), and (iii) agriculture extension. Now there is much talk about commercialization of agriculture.

The solutions that are fundamental to generate wellbeing and prosperity from existing relatively poor and under-productive irrigated agriculture are never systematically identified, pursued and mainstreamed into policy and program initiatives. Such a negative situation was the result of a governance culture where most of the time it was the need of the government to rather spend the money than to sustainably enrich the people in terms of their well being and institutional capability development. Let us explore some of these solutions, which, for me, are more institutional.

\section{Localization}

Most of the financial resources have been invested in centralized large scale public irrigation systems. It was good for centralized control on irrigation water administration but bad for promotion of local ownership, governance, modernization, regular maintenance, and operation of these systems. Lack of local ownership, governance, modernization, regular maintenance, and operation of the irrigation systems seriously affected timely, effective and fair decision making in the irrigation system, whether for water acquisition, allocation, distribution, maintenance and operation, or resource mobilization.

Indeed, the irrigation bureaucracy was restructured at times. But these restructurings were more motivated to bypass the establishment of a local governance framework and keep intact the centralized sectoral control on public irrigation systems. Restructuring has not brought irrigation closer to the farmers nor has it contributed in developing local ownership, governance, modernization, regular maintenance and operation of the irrigation systems.

Localizing public irrigation systems is a pre-requisite to developing sustainable institutional infrastructure in them. Localization may be defined as the reform process of centralized public irrigation system whereby it not only operationally belongs to the local water users association (WUA), relevant local government unit, and the community having a larger stake in the irrigation, but that the representatives of the WUA, local government unit and community are also mutually accountable to govern, maintain and operate the irrigation system in the best local interest.

The National Water Resources Strategy (2002), wherein the government takes initiative to apply river basin approach to develop and manage water resources, may help to fundamentally reform public irrigations systems by localizing their governance (Upadhyay 2008). Water access mechanisms developed under this approach may enable institutionalizing an imaginative arrangement that encourages representation of stakeholders having roots in the local setting.

\section{Resource Base}

The tragedy of public irrigation systems in Nepal is that they are poor and less productive despite their richness in natural endowment. If the water, land and human resources of an irrigation system are combined, perhaps they form the richest resource base in the country. 
Relative poverty and under-productivity of these irrigation systems is clearly the function of their lack of local grounding and operational autonomy. Centralized governance of local irrigation systems does not allow them to be innovative, negotiative, efficient and equitable in the local context. As irrigation system inherently has an indigenous civilizational identity because of its nature and history of the local water, land and people, centralizing their governance deprives them from taking any initiative to get benefits from the comparative advantages it offers, and innovatively govern, finance and modernize their system. As such, no capable person will like to remain engaged in an area where s/he cannot envision any socioeconomic prosperity.

Localization of erstwhile centralized irrigation systems would recognize and appreciate the rich resource base of the irrigation systems and their comparative advantages. This will help them indigenously promote their resource base more productively and efficiently, and that will attract the capable people to add value and dynamism to the agricultural enterprise.

\section{Cooperative Venture}

A public irrigation system functioning as a localized irrigated agricultural enterprise will be a cooperative venture. WUAs, local government units, and other stakeholders will be members of the cooperative ventures. Members will share the cost and benefits of the enterprise and they will be mutually accountable to one another. The members' roles and responsibilities will be specified in the regulations of each cooperative venture and will be recognized by law. Each cooperative venture will be able to act as a legal person in the matters of borrowing, trade, marketing, representation, agro-industries, and any other joint activity with other legal persons that support and promote commercialization and environmental quality of agriculture.

A strong localized cooperative venture can holistically nurture, manage and harness its resource base and adapt to climate change requirements. But we must be very strategic in this context. In the name of climate change and food security requirements, a section of powerful global players are promoting their commercial interests at the cost of indigenous sustainability and long term local viability of Nepalese farming. For example, efforts are being made under bilateral projects to kill sustainability and long term local viability of Nepalese agriculture by introducing hybrid seeds (Bhattarai 2011). We may, on the other hand, learn from a Chinese experience. What was done there sounds simple: Seeds from the historically warm ecological region were used in cultivation in a region with increasing temperature (the local government and farmers' water users association became the cooperative partners in this seed transfer and adaptation process) triggered by climate change (Reidinger 2011). ${ }^{1}$ This experience showed that even in the context of climate change, strong local institutions become the effective institutional vehicle for inter-regional transfer and use of seeds, the most important component for improved agricultural productivity.
This solution does not entail as much time and cost that breeding of new seed variety might have taken.

Kautilya (321 BC to $290 \mathrm{BC}$ ), the sage statesman of Magadh Desh, seems to have learned from Confucius, when he said: "There is enemy equal to hunger. Poverty is death while living. There is nothing uneatable for a hungry one. The poor one is despised (hated) by his own wife. Learning is wealth for the poor."

The ultimate question is: Can we still afford to refuse learning?

\section{Conclusion}

Food security is critical for both orderly state affairs and personal wellbeing. Heavily invested, underproductive and poorly performing public irrigation systems in Nepal need to be restructured as a localized naturally endowed legal cooperative venture with specified land, water and human resource-base, which is autonomously governed by mutually accountable local stakeholders. Such institutional alternative helps make these systems resilient and adaptive to the requirements of increasing productivity, absorbing youth to the local gainful enterprise system and climate change phenomenon.

Upendra Gautam, PhD from Panjab University, Chandigarh, India. has been in the field of irrigation management and institutional development for more than 25 years. He has research and work experience in Nepal, China, India, Guyana and the Philippines. As a founding chairman/member, he has been instrumental in the establishment and development of Public Administration Campus, Tribhuvan University; CMS Nepal, a consulting firm; Nepal Engineering College; Farmer Managed Irrigation Systems (FMIS) Promotion Trust, Jalsrot Vikas Sanstha; and China Study Center.

Corresponding Address: cmsug_cms@wlink.com.np

\section{Endnote}

1 In informal communications of 27 April and 23 May 2011 between the author and Richard Reidinger, formerly task manager/economist of the World Bank Projects in China, Reidinger wrote: "Of late, they have been instrumental in 'Mainstreaming of Climate Change Adaptation into Irrigated Agriculture Project,' which was attached to the huge Irrigated Agricultural Intensification III Project or IAIL3 just closed at the end of 2010. WUAs have become a key part of both IAIL3 in terms of providing a primary mechanism to teach the farmers about climate change adaptation as related to irrigation actions the farmers can take to mitigate climate change impacts, etc. One of the actions taken by farmers with the WUAs under the project was to change crop varieties... To compensate for warming temperatures, China has recently been using a little trick... that might also work in Nepal. They have been introducing varieties from northern areas into southern areas (as well as breeding for drought resistance). This type of varietals change is relatively easy and would save the plant breeders a lot of time and effort" (Reidinger 2011). 


\section{References}

Abernethy, C.L., 2000, 'Management of water and irrigation facilities in effective irrigators organization for participatory management', in the proceedings of the workshop organized by DSE-MARD and MAF, Quy Nhon, Vietnam.

Acharya, A., 2011, 'Lost to the land', Nepali Times (Kathmandu), May 6-12.

Bhattarai, A., 2011, 'Better ways than Monsanto', The Kathmandu Post, November 1, 2011.

Devkota, D.D., 2002, 'FMIS in the Highlands of Nepal' (in Nepali, unpublished).

Dhawan, H., 2008, 'India world's largest remittance recipient', Times of India (New Delhi), June 20, 2008.

Gautam, U. and G. Khaniya, 2010, 'Farmer managed irrigation systems in Nepal: People-centered governance alternative, in S.R. Devkota (ed.), Nepal in the 21st Century, Hauppauge, NY: Nova Science Publishers.

Khaniya, G., 2005, Traditional Water Management Practices: A Case Study of Bhaktapur City, Kathmandu: Jalsrot Vikas Sanstha/Nepal Water Partnership.

MOAC, 2010, Statistical Information on Nepalese Agriculture 2009/2010 (2066/67), Kathmandyu: Ministry of Agriculture and Cooperatives, AgriBusiness Promotion and Statistics Division.

Nepali, C., 1965, 'Shasan byabastha ra sudhar karya' ('Administrative system and reform activity'), in General Bhimsen Thapa ra Tatkalin Nepal (General Bhimsen Thapa and Then Nepal), in Nepali, Kathmandu: Ratna Pustak Bhandar.

Paudel, S.N., 2011, personal communication (October).

Paudel, S.N., 2059 (2002 AD), Irrigation in Nepal (in Nepali), Kathmandu: Jalsrot Vikas Sanstha/Nepal Water Partnership.

Pradhan, P., 1989, Patterns of Irrigation Organizations in Nepal: A Comparative Study of 21 Farmer Managed Irrigation Systems, Colombo, Sri Lanka: International Irrigation Institute (IRRI).
Pradhan, P., 2011, 'Revitalizing irrigation systems for food security: Vision and approaches in Nepal irrigation systems', Keynote Address at the National Conference on Water, Food Security and Climate Change in Nepal, sponsored by the International Water Management Institute (IRRI) and Nepal Department of Irrigation (DOF), Kathmandu, November 23-24.

Pun, S., 2001, 'Role of gender in Sali-Nadi (Shankhu Rajkulo) irrigation management: A case study, in U. Gautam and S. Rana (eds.), Challenges to Farmer Managed Irrigation Systems: Proceedings of the International Seminar, Kathmandu: Farmer Managed Irrigation Systems Promotion Trust.

Reidinger, R., 2011, personal communications (see Endnote No.1).

Sapkota, C., 2011, 'Food security in Nepal', Republica (Kathmandu), February 22.

Stedman, L., 2009, 'ASIA: ADB study finds climate change is impacting on water and food security (08/09/09)', London: IWA Publishing. URL: www.iwapublishing. com/template.cfm?name=news369.

Tiwari, S.R., 2002, 'Lichchhavi waterworks around the capital region', in S.R. Tiwari, The Brick and the Bull, Kathmandu: Himal Books.

Upadhyay, S.N., 2008, 'Legal and policy aspects of river basin management', in Stakeholders' Orientation in River Basin Management: Preliminary Training Manual, unpublished paper prepared by CMS Nepal for the World Wildlife Fund/Nepal and the Nepal Water and Energy Commission Secretariat.

Vaidya, Y.N., 1999, 'Food security in Nepal', in R. Adhikari and N. Bharadwaj (eds.), Food Security Prospects and Challenges, Report on the National Workshop on Food Security, Kathmandu: Forum for Protection of Public Interest (Pro Public), SEWA Nepal and Action Aid/Nepal.

WECS, 2002, National Water Strategy, Nepal, Kathmandu: Government of Nepal, Water and Energy Commission Secretariat (WECS).

Wright, D., 2000, History of Nepal, New Delhi: Aadarsha Enterprises.

\section{Call For Nomination for the Excellence Award 2012}

Many people and institutions have rendered their services in the field of water, energy and/ or environment. HYDRO Nepal Excellence Award is established to recognize their efforts and honor them. HYDRO Nepal journal solicits nominations from among the experts, professionals or other individuals, institutions involved in the pursuit of excellence in the field of water, energy or/ and environment sector in Nepal for the annual HDRO Nepal Excellence Award for the year 2012.

Please send one page brief of the work and contributions of the nominated person or an institution for the year 2012 (and previous to that). Please include the nominee's full name, address, contact phone number and email address, including your own phone and email. The deadline for submission of nominations is May 20, 2012.

Nominations will be evaluated by a three person Evaluation Committee consisting of prominent authorities in the sector. The Evaluation \& Selection Committee will decide the winner by June 30, 2012. The Decision of the Evaluation Committee will be final. The winner will be announced in the 11th Issue of HYDRO Nepal Journal in July 2012. 